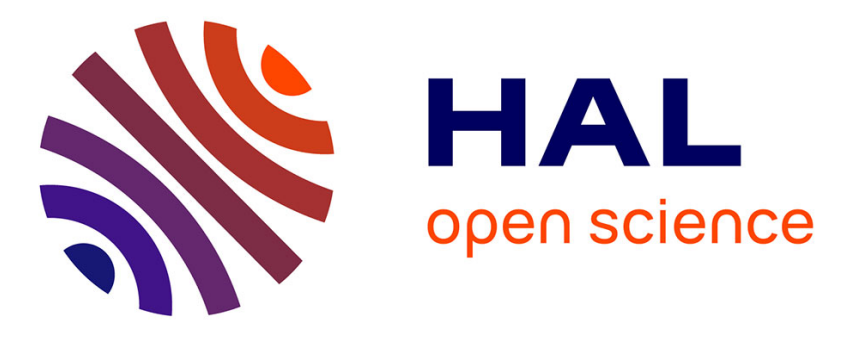

\title{
Pollen productivity estimates and relevant source area of pollen for selected plant taxa in a pasture woodland landscape of the Jura Mountains (Switzerland)
}

Florence Mazier, Anna Brostrom, M.J. Gaillard, Shinya Sugita, Pascal Vittoz, Alexandre Buttler

\section{To cite this version:}

Florence Mazier, Anna Brostrom, M.J. Gaillard, Shinya Sugita, Pascal Vittoz, et al.. Pollen productivity estimates and relevant source area of pollen for selected plant taxa in a pasture woodland landscape of the Jura Mountains (Switzerland). Vegetation History and Archaeobotany, 2008, 17, pp.479-495. 10.1007/s00334-008-0143-0 . halshs-00959482

\section{HAL Id: halshs-00959482 \\ https://shs.hal.science/halshs-00959482}

Submitted on 14 Mar 2014

HAL is a multi-disciplinary open access archive for the deposit and dissemination of scientific research documents, whether they are published or not. The documents may come from teaching and research institutions in France or abroad, or from public or private research centers.
L'archive ouverte pluridisciplinaire HAL, est destinée au dépôt et à la diffusion de documents scientifiques de niveau recherche, publiés ou non, émanant des établissements d'enseignement et de recherche français ou étrangers, des laboratoires publics ou privés. 


\title{
Pollen productivity estimates and relevant source area of pollen for selected plant taxa in a pasture woodland landscape of the Jura Mountains (Switzerland)
}

\author{
Florence Mazier • Anna Broström • \\ Marie-José Gaillard · Shinya Sugita • \\ Pascal Vittoz $\cdot$ Alexandre Buttler
}

Received: 11 July 2007 / Accepted: 23 October 2007/Published online: 30 January 2008

(C) Springer-Verlag 2008

\begin{abstract}
Relevant source area of pollen (RSAP) and pollen productivity for 11 key taxa characteristic of the pasture woodland landscape of the Jura Mountains, Switzerland, were estimated using pollen assemblages from moss polsters at 20 sites. To obtain robust pollen productivity estimates (PPEs), we used vegetation survey data at a fine spatial-resolution $\left(1 \times 1 \mathrm{~m}^{2}\right)$ and randomized locations for sampling sites, techniques rarely used in
\end{abstract}

Communicated by M.J. Bunting.

F. Mazier $(\bowtie) \cdot$ A. Buttler

Laboratoire de Chrono-Ecologie, UMR 6565 CNRS,

Université de Franche-Comté, 16 route de Gray,

25030 Besançon Cedex, France

e-mail: florence.mazier@hik.se; florencemazier@yahoo.fr

F. Mazier · M.-J. Gaillard

School of Pure and Applied Natural Sciences,

39182 Kalmar, Sweden

A. Broström

Quaternary Science, GeoBiosphere Science Centre,

Lund University, Sölvegatan 12, 22362 Lund, Sweden

\section{S. Sugita}

Department of Ecology, Evolution and Behaviour,

University of Minnesota, 1987 Upper Bufford Circle, St Paul,

MN 55108-6097, USA

\section{P. Vittoz}

Département d'écologie et évolution, Université de Lausanne, Faculté des géosciences et de l'environnement (FGSE),

Bâtiment Biophore, 1015 Lausanne, Switzerland

\section{A. Buttler}

Laboratoire des Systèmes écologiques - ECOS,

Ecole polytechnique fédérale de Lausanne (EPFL) et Institut fédéral de recherches WSL, Antenne romande, Case postale 96, 1015 Lausanne, Switzerland palynology. Three Extended $R$ value (ERV) submodels and three distance-weighting methods for plant abundance calculation were applied. Different combinations of the submodels and distance-weighting methods provide slightly different estimates of RSAP and PPEs. Although ERV submodel 1 using $1 / d$ ( $d=$ distance in meters) best fits the dataset, PPE values for heavy pollen types (e.g. Abies) were sensitive to the method used for distanceweighting. Taxon-specific distance-weighting methods, such as Prentice's model, emphasize the intertaxonomic differences in pollen dispersal and deposition, and are thus theoretically sound. For the dataset obtained in this project, Prentice's model was more appropriate than other distanceweighting methods to estimate PPEs. Most of the taxa have PPEs equal to (Fagus, Plantago media and Potentillatype), or higher (Abies, Picea, Rubiaceae and Trollius europaeus) than Poaceae ( $\mathrm{PPE}=1)$. Acer, Cyperaceae, and Plantago montana-type are low pollen producers. This set of PPEs will be useful for reconstructing heterogeneous, mountainous pasture woodland landscapes from fossil pollen records. The RSAP for moss polsters in this semiopen landscape region is ca. $300 \mathrm{~m}$.

Keywords Pasture woodland landscape .

Relevant source area of pollen (RSAP) .

Pollen productivity estimates (PPE) .

Extended $R$ value submodels .

Distance-weighting methods .

Pollen-vegetation relationship $\cdot$ Moss polsters

\section{Introduction}

Fossil pollen records offer great potential for estimating past vegetation composition and abundance around a 
pollen sampling point (e.g. Gaillard et al. 2007; Sugita et al. 1999; Andersen et al. 2006). The reliability of such vegetation/landscape reconstructions requires a detailed understanding of the spatial scale represented by pollen assemblages, involving the differentiation between local and regional pollen input (Sugita 1994, 2007a, b). Pollen productivity and dispersal characteristics are two of the most important factors influencing the pollen representation of the surrounding vegetation (e.g. Prentice 1985; Sugita 1994). Pollen productivity estimates (PPE) for major plant taxa within forested areas have been produced in various regions in northern Europe and North America (e.g. Bunting et al. 2005; Calcote 1995). Sugita et al. (1999) and Broström et al. $(1998,2004,2005)$ explored the pollen-vegetation relationship in open and semi-open landscapes of southern Sweden. Pollen productivity for key tree and herb taxa of the region were estimated (Sugita et al. 1999; Broström et al. 2004). Relevant source area of pollen (RSAP) for small lake basins (Sugita et al. 1999) and moss polsters (Broström et al. 2005) was calculated. Studies on the pollen-vegetation relationship and estimates of pollen productivity and RSAP have been limited in central Europe until recently. Soepboer et al. (2007a) produced PPEs for a number of tree and herb taxa using pollen assemblages from lake surface sediments in the agricultural landscape of the Swiss Plateau and evaluated them by a simulation approach (Soepboer et al. 2007b, this volume).

The present study is the first contribution to the development of robust tools for the reconstruction of past landcover/vegetation abundance in the mountainous landscapes of central Europe. The pasture woodland vegetation of the Jura Moutains, Switzerland, is a complex mosaic of trees, shrubs and open grassland. This semi-open landscape patchiness is at the origin of a very high vegetation heterogeneity and biodiversity (Gobat et al. 1989). Spatial patterns of vegetation are the result of ancient, traditional land-use practices combining cattle grazing and forestry. Sjögren (2005, 2006) and Sjögren and Lamentowicz (2007) suggests that these pasture woodland landscapes came into existence in the 17th and 18th centuries. Therefore the functioning of this ecosystem is partly contingent on a significant history of human impact, thus requiring that integrated strategies for conservation and sustainable management of ecosystems incorporate an understanding of both short and long term responses to climate and human activities. Therefore there is a need for appropriate tools to reconstruct past vegetation abundance/land cover as a means to answer questions related to possible links between human-impact, climate change, degree of landscape openness and patchiness, and biodiversity.

Our study uses 20 pollen assemblages (moss polsters) and related vegetation abundance data collected for each plant taxon in distance increments of $1 \mathrm{~m}$, out to $1500 \mathrm{~m}$, from each of the 20 pollen sampling points. Firstly this very detailed vegetation survey was used to assess how goodness of fit and parameter estimates using Extended $R$ value (ERV) submodels are influenced by distanceweighting functions such as inverse distance $(1 / d)$, inversesquared distance $\left(1 / d^{2}\right)$ and Prentice's (pollen dispersal) model (Calcote 1995; Webb III et al. 1981; Prentice 1985; Prentice and Webb III 1986; Sugita 1994). Secondly it was used to compare parameters and model-data goodness-offit using the three ERV submodels currently available (Parsons and Prentice 1981; Prentice and Parsons 1983; Sugita 1994), and thirdly to estimate PPEs for selected plant taxa and the size of the RSAP for moss polsters in the study area.

\section{Theoretical background}

Pollen productivity estimates (PPEs)

The pollen-vegetation relationship can be described as a linear function as below, when pollen loading, $y$, and plant abundance, $x$, of individual taxa are measured in absolute units (Andersen 1970; Prentice 1985, 1988; Sugita 1993, 1994).

$y_{i k}=\alpha_{i} x_{i k}+\omega_{i}$,

where

$y_{i k}$ : represents pollen loading of species $i$ at site $k$,

$x_{i k}$ : plant abundance of species $i$,

$\alpha_{i}$ : pollen representation factor for species $i$ (speciesconstant), and

$\omega_{i}$ : background pollen loading for species $i$ (speciesconstant).

The slope (i.e. pollen representation factor $\alpha_{i}$ ) of this linear function represents the pollen productivity of an individual taxon, when the plant abundance, $x_{i k}$, is properly measured by taking into account:

1. distance between the sedimentary basin where pollen samples are collected, and source plants,

2. total plant abundance at given distances,

3. species-specific pollen dispersal and deposition in given atmospheric conditions,

4. the size of the sedimentary basin.

The intercept (i.e. background pollen loading, $\omega_{i}$ ) represents pollen loading coming from beyond the area in which plant abundance is surveyed and measured.

When pollen percentages, instead of pollen loading, are used, this relationship becomes non-linear because of the "closed universe" of pollen percentage data (Fagerlind 
1952; Prentice and Webb III 1986). The ERV model, with its three submodels, was developed to estimate $\alpha_{i}$ in equation (1) for individual taxa when only pollen percentages are available (Parsons and Prentice 1981; Prentice and Parsons 1983; Sugita 1994). One taxon is set to unity $(\alpha=1)$, and the PPE of the other taxa are calculated relative to this reference taxon. The submodels differ in their assumptions about the background pollen component. ERV submodels 1 and 2 (Parsons and Prentice 1981; Prentice and Parsons 1983) are designed for datasets where both pollen and vegetation data are expressed in percentages. ERV submodel 1 assumes that the background pollen term is constant when expressed as a percentage, whereas ERV submodel 2 assumes that the species specific background component is constant relative to the total plant abundance of all the taxa involved. ERV submodel 3 (Sugita 1994) is used when pollen data are expressed in percentages while the vegetation data is in absolute values; the model assumes constant background pollen loading. All three submodels can be used for any dataset and should give comparable results if the background pollen loading is low compared to the total pollen loading (Jackson and Kearsey 1998). Large differences in pollen productivity between taxa, and in vegetation composition among sites might strain the approximation of submodel 1, while submodel 2 will be less appropriate when there are large differences in total plant abundance among sites (Prentice and Parsons 1983).

\section{Relevant source area of pollen (RSAP)}

The size of the pollen source area reflected in pollen assemblages from similarly-sized lakes and mires varies from region to region. It depends mainly on the spatial distribution (local and regional) and size of vegetation patches (Sugita 1994; Bunting et al. 2004; Broström et al. 2005; Nielsen and Sugita 2005). Sugita (1994) proposed the "relevant source area of pollen" (RSAP) as a sound theoretical definition of the spatial scale of vegetation represented by pollen assemblages. The RSAP can be defined as the distance at which the goodness-of-fit of the pollen-vegetation relationship to the model (e.g. ERV submodels) doesn't improve (Sugita 1994). This also means that the differences in pollen abundance among similarly-sized sites represent differences in plant abundance within the RSAP, superimposed on a constant pollen background coming from beyond the RSAP (Sugita 1994, 1998, 2007b). The RSAP was estimated for various basin sizes and vegetation types using both empirical and simulated pollen-vegetation datasets (Sugita 1994; Sugita et al. 1999; Broström et al. 2005; Bunting et al. 2005; Calcote 1995; Nielsen and Sugita 2005).

\section{Materials and methods}

Study area

The study was conducted in pasture woodlands of the Swiss Jura Mountains located in the Parc Jurassien Vaudois $\left(6^{\circ} 13^{\prime} 50^{\prime \prime} \mathrm{E}, 46^{\circ} 32^{\prime} 50^{\prime \prime} \mathrm{N}\right)$ and its surroundings. The area comprises the montaine and subalpine zones with elevations between 1,100 and $1,550 \mathrm{~m}$ a.s.l. The climate is suboceanic with mean annual temperatures of $3-5^{\circ} \mathrm{C}$ (Bloesch and Calame 1994), and an annual precipitation of $1,600 \mathrm{~mm}$ (including $400 \mathrm{~mm}$ of snow) regularly distributed over the year. The soils are relatively dry due to the presence of calcareous layers with a high permeability (Gallandat et al. 1995). The vegetation season is short (120-135 days).

Pasture woodlands are traditional, semi-natural ecosystems with natural regeneration of grassland and woodland. The modern landscape is characterized by a gradient in the degree of openness, from open grassland to semi-open wooded pasture and relatively opens forests (more than $60 \%$ of the total vegetation cover is characterised by arboreal vegetation). The forest patches are located mainly on rock outcrops and steep slopes, whereas grasslands are located on level surfaces or in anticlinal valleys. Coniferous forest, with Picea abies, scattered Abies alba and Acer pseudoplatanus, is the dominant vegetation type above $1,300 \mathrm{~m}$ a.s.1. Deciduous forests dominated by Fagus sylvatica are found on southfacing slopes below $1,400 \mathrm{~m}$ a.s.l., where there is no longer any cattle grazing. Part of the vegetation of the Parc Jurassien Vaudois was surveyed and mapped by Vittoz (1998). Thirty-two plant communities were described in terms of vegetation unit, structure and species composition (554 vascular plants) using the integrated synusial approach (Gillet and Gallandat 1996).

Selecting the location of sampling sites

Sites for collection of pollen and vegetation data were selected to represent past pasture woodland landscapes in terms of species composition and vegetation structure. Broström et al. (2005) show the importance of random selection of site locations in the landscape to obtain reliable RSAP and PPE. Therefore the centre of each of the 20 sites was randomly placed on the existing vegetation maps (Fig. 1), with the constraints that each site centre was at least $200 \mathrm{~m}$ from the edge of the existing vegetation maps, and that the site centres were at least $400 \mathrm{~m}$ apart. Thus a $200 \mathrm{~m}$ radius circle around any site centre did not overlap with that round any of its neighbours. 
Fig. 1 The study area in the pasture-woodland landscape of the Jura Mountains,

Switzerland. Location of 20 sample points (dots) for collection of pollen samples (moss polsters) randomly distributed on the existing vegetation maps. The limit of the area used for the complete vegetation survey data outside the vegetation maps, up to $1,500 \mathrm{~m}$ from each sampling point, is indicated

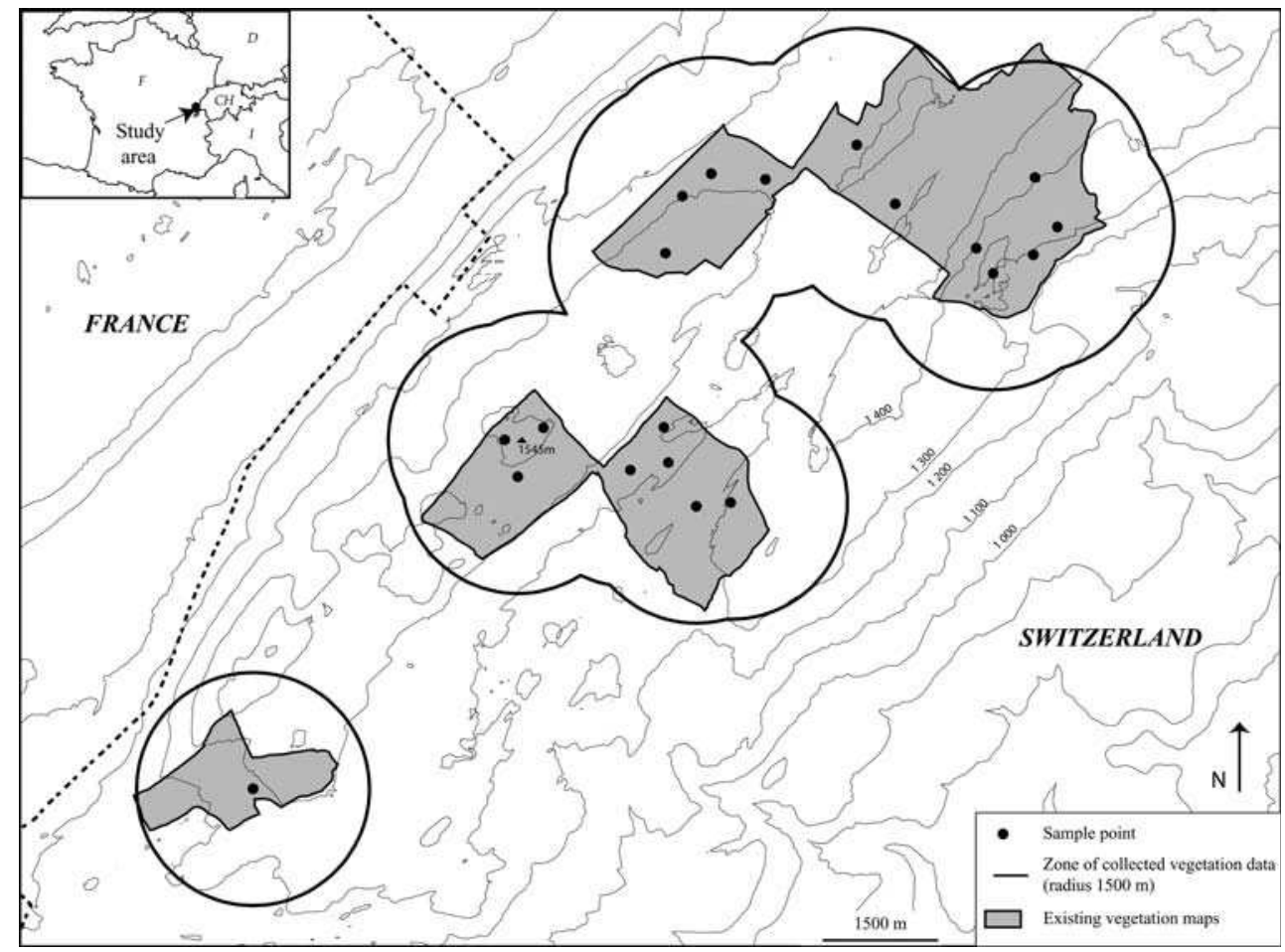

Pollen data

Moss polsters are commonly used as surface samples in studies of pollen-vegetation relationships (e.g. Broström et al. 2004; Bunting et al. 2005). They are assumed to record an average of several years of pollen deposition (e.g. Bradshaw 1981; Heim 1970), which is recommended to avoid annual variations in pollen productivity (Hicks 2001; Hicks et al. 2001; Räsänen et al. 2004; Van der Knaap et al. 2001). However, contradictory views have been presented as to the time span of pollen deposition retained in mosses, which has been estimated to be between one and 15 years, depending on the type/species of moss collected and the part of the moss used for analysis (Boyd 1986; Bradshaw 1981; Caseldine 1981; Crowder and Cuddy 1973; Cundill 1991; Heim 1970; Mulder and Janssen 1998, 1999; Räsänen et al. 2004). In order to avoid moss samples that would include primarily the pollen rain of the year of sampling, the whole moss (both green and brownish part) down to the soil was sampled. It was assumed that the whole moss registers more than one year of pollen rain.

Several subsamples of moss from one or different species were collected within a circular area of $0.5 \mathrm{~m}$ radius around the centre of each site and amalgamated into one sample per point (Broström et al. 2004). All 20 samples were processed following standard methods (Faegri and Iversen 1989). A minimum of 850 pollen grains (aquatics and spores excluded) per sample was counted and identified (microscope at $400 \times$ magnification) by Jacqueline van Leeuwen (Institute of Plant Sciences, Bern, Switzerland) to the lowest taxonomic level possible using pollen keys (Moore et al. 1991; Punt et al. 1976-1995; Reille 1992-1998) and the reference collection at the Institute of Plant Sciences.

\section{Vegetation data}

Since reliable PPEs are obtained when pollen samples are compared with the surrounding vegetation at or beyond the relevant source area of the pollen sample (RSAP), the vegetation survey should cover an area larger than the RSAP (Broström et al. 2004, 2005). A simulation approach (Sugita 1994; Sugita et al. 1999) was applied to estimate the RSAP using simple, hypothetical landscapes similar to the pasture woodlands of the study area. Simulations show that the predicted RSAP is the area within a 700-800 m radius for moss polsters (Mazier 2006). Accordingly, we surveyed the vegetation composition from each pollen sampling point out to a radius of $1,500 \mathrm{~m}$. Plant abundance was estimated in concentric rings of various widths out to the $1,500 \mathrm{~m}$ limit. This strategy enables us to calculate the distance-weighted plant abundance of individual taxa, which is required to calculate PPEs using ERV submodels. We used a modified version of the vegetation survey scheme described in Broström et al. (2004) for our mountainous landscape (Fig. 2). The vegetation was surveyed in the summer of 2003 at three different spatial scales in as much detail as possible using time and cost- 


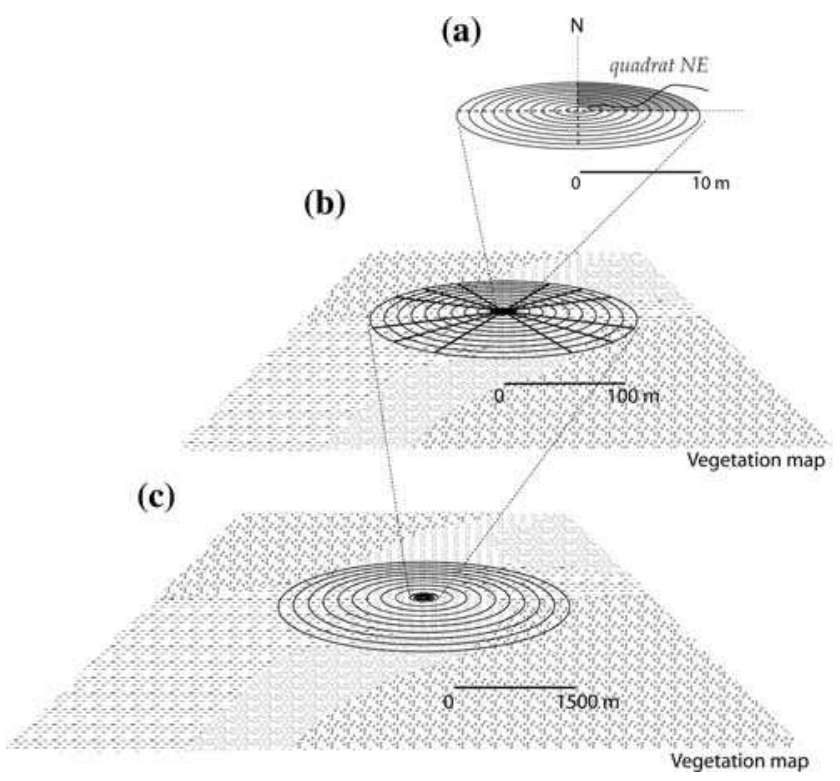

Fig. 2 Design adapted from Broström et al. (2004) for the collection of vegetation data from 0 up to $1,500 \mathrm{~m}$ from each pollen sampling point. a Within 0-10 m distance (increment $1 \mathrm{~m}$ ): vegetation survey per quadrate and visual estimation of plant cover, (b) within 10$100 \mathrm{~m}$ (increment $10 \mathrm{~m}$ ): extraction from vegetation maps and database (Vittoz 1998) for herb cover and field survey for tree cover along 12 transects equally distributed and, (c) beyond $100 \mathrm{~m}$ (increment $1 \mathrm{~m}$ ): interpretation of vegetation types CIR-aerial photos based on Vittoz's classification (1998)

effective methods, combining field observations, existing vegetation maps, and classification of aerial photos:

1. Vegetation survey within the area between 0 and $10 \mathrm{~m}$.

Because of the limited dispersal of most herb pollen, precise vegetation data is needed at this scale. The method was inspired by the "walking in circles" approach of Broström et al. (2004). The percentage cover of each plant species (trees, shrubs and herbs) was estimated visually within a metre-wide concentric ring for each quadrat (N-E, $\mathrm{E}-\mathrm{S}, \mathrm{S}-\mathrm{W}$ and $\mathrm{W}-\mathrm{N}$ ). The use of quadrats (not applied by Broström et al. 2004) makes visual estimation of percentage cover in the field easier. An average of the percentage covers for the four quadrats was calculated for each 1 -m-wide concentric ring.

2. Vegetation data within the area between 10 and $100 \mathrm{~m}$.

Since vegetation maps and species composition were available for each vegetation type mapped (Table 1-taxa compositions within each vegetation type according to Vittoz 1998), herb composition within each concentric ring was extracted from the digital vegetation maps using a Geographical Information System (GIS). Precise data for trees were obtained in the field from 12 equally spaced transects from the pollen sampling point out to $100 \mathrm{~m}$ using a compass and measuring tape. Along each transect, the cover of tree crowns was estimated within a $1 \mathrm{~m}$ wide band. An average of the tree percentage covers along the 12 transects was calculated for each concentric $10 \mathrm{~m}$ ring.

3. Vegetation data between 100 and $1,500 \mathrm{~m}$.

Vegetation outside the $100 \mathrm{~m}$ radius was extracted from Colour Infra Red (CIR) aerial photographs (July 1986) at a scale of 1:10,000. Species composition of vegetation units not existing in the two surveys described above were surveyed in the field or extracted from the forest inventory of the canton of Vaud. The data on species composition of the vegetation units was obtained at the same degree of detail used for the survey between $10 \mathrm{~m}$ and $100 \mathrm{~m}$. The identified vegetation units were digitized into vector format using ARCVIEW (version 9.0). The software calculated the percentage coverage of each vegetation type in each concentric ring (increment $1 \mathrm{~m}$ ) which can be converted to plant abundance using the data from Table 1.

Analytical methods

\section{Selection of taxa included in the analysis}

Raw pollen counts and plant abundance data from 20 sites were used for the calculation of PPEs. In order to understand the pollen-plant relationship at the taxonomic level used in pollen analysis, plant taxa were grouped according to pollen morphological types (Table 2-taxa used in the final analysis). The resulting pollen-vegetation dataset includes 20 sites and 28 plant taxa (six tree taxa and 22 herb taxa). These taxa were recorded in both pollen and vegetation data and in both modern and fossil pollen assemblages (Sjögren, personal communication).

The 28 selected taxa represent $53-85 \%$ of the total pollen count and $64-71 \%$ of the total plant cover at each site. Some of the taxa excluded from the analysis contribute significantly to the total pollen count, such as Pinus, Quercus, Fraxinus and Betula; these four taxa represent between 10 and $22 \%$ of the pollen spectra. However, they were rarely or never found in the vegetation of the study area (Vittoz 1998). Pinus, Betula and Fraxinus were found as isolated trees at some places in the study area. In the composition of the vegetation extracted from the vegetation map within $1,500 \mathrm{~m}$ from each site centre, some taxa (e.g. Valeriana, Melampyrum, Rubus) were often found in the vegetation. Because these taxa are rarely found in the modern and past pollen spectra (Sjögren, personal communication) they were not included in the analysis.

For the purpose of the PPEs calculations, the vegetation data (percentage cover from field survey and/or 
Table 1 Species composition of the vegetation types extracted from Vittoz (1998)

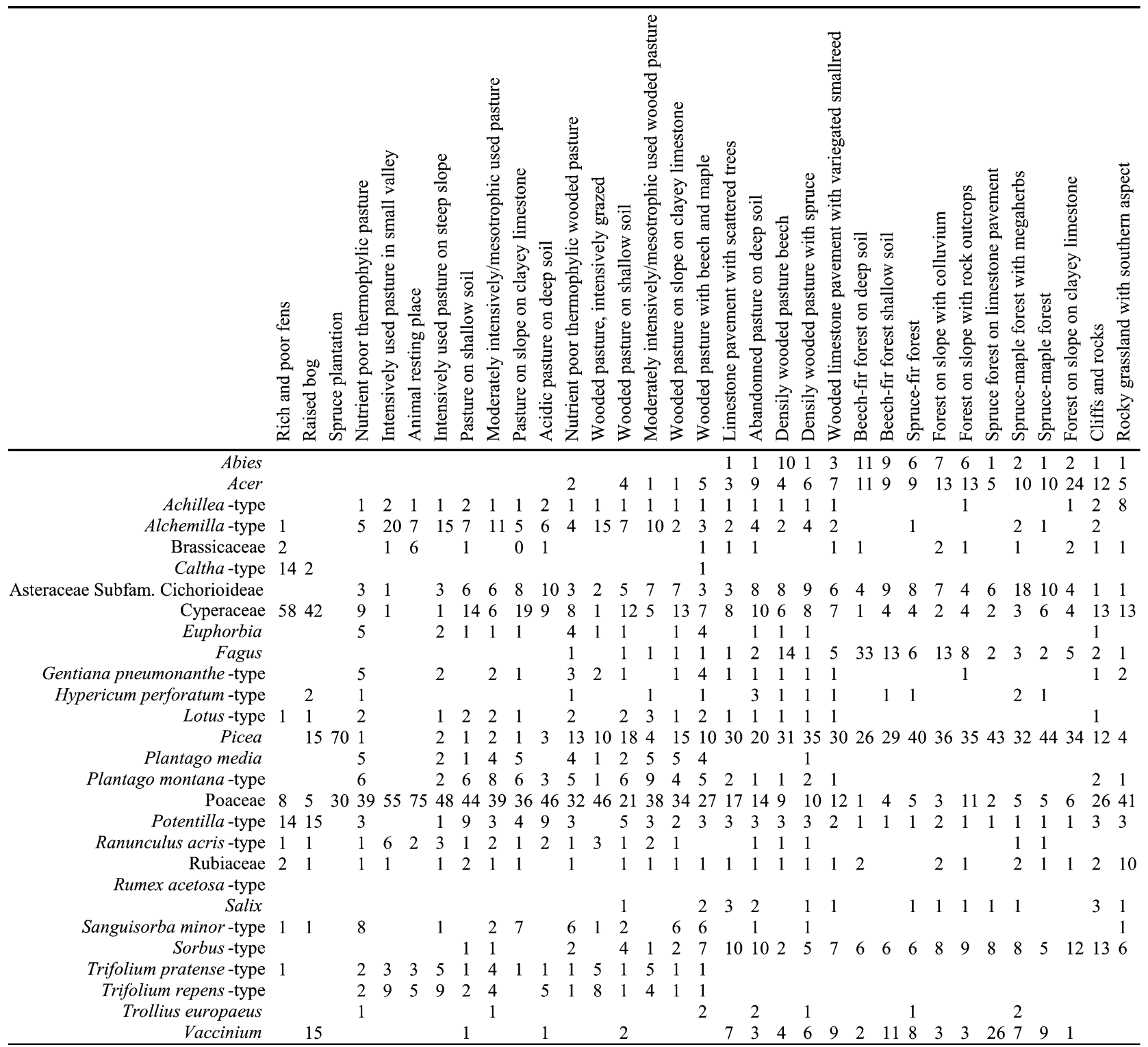

Percentages were adjusted to 28 pollen taxa which were recorded in both the pollen and plant datasets

GIS) were recalculated on the sum of the 28 selected taxa. The dominant taxa in the vegetation within $1,500 \mathrm{~m}$ from the site centre are Picea, Poaceae, Fagus, Acer, Cyperaceae and Abies. In the pollen assemblages, the dominant taxa are Picea, Poaceae, Fagus and Abies. Some taxa such as Alchemilla, Asteraceae SF Cichorioideae, Sorbus and Vaccinium are well represented in the vegetation but underrepresented in the pollen assemblages. Other taxa are poorly represented in both pollen and vegetation data. As a consequence, 17 taxa were excluded from the final analysis because either they didn't present a spread of values (proportions) within the vegetation-pollen datasets which is required for the calculation (Broström et al. 2004), or their pollen frequencies and/or plant abundance values were less than $1 \%$ at several sites. The excluded 17 taxa represent 29$33 \%$ of the vegetation and $3-19 \%$ of the pollen assemblages. One site/pollen sample with an unusually high pollen value for Potentilla type was excluded. Statistically speaking, the number of sites should be twice the number of taxa used (Sugita, personal communication). Therefore, further analyses were restricted to 19 sites and 11 (four tree and seven herb) taxa from the original 28 selected. 
Table 2 Plant taxa in the vegetation survey harmonized to pollen morphological types

\begin{tabular}{|c|c|c|c|c|}
\hline $\begin{array}{l}\text { Pollen morphological } \\
\text { type }\end{array}$ & $\begin{array}{l}\text { Corresponding plant taxa } \\
\text { in vegetation }\end{array}$ & $\begin{array}{l}\text { Diameter of pollen } \\
\text { grains }(\mu \mathrm{m})\end{array}$ & $\begin{array}{l}\text { Fall speed } \\
(\mathrm{m} / \mathrm{s})\end{array}$ & $\begin{array}{l}\text { Reference for fall } \\
\text { speed of pollen }\end{array}$ \\
\hline Abies & Abies alba & & 0.12 & Eisenhut 1961 \\
\hline Acer & Acer pseudoplatanus & & 0.056 & Sugita 1993, 1994 \\
\hline Cyperaceae & Cyperaceae & & 0.035 & Sugita et al. 1999 \\
\hline Fagus & Fagus sylvatica & & 0.057 & Gregory 1973 \\
\hline Picea & Picea abies & & 0.056 & Eisenhut 1961 \\
\hline Plantago media & Plantago media & 28.9 & 0.024 & \\
\hline Plantago montana-type & Plantago atrata & 32.2 & 0.030 & \\
\hline Poaceae & Poaceae & & 0.035 & Sugita et al 1999 \\
\hline Potentilla-type & $\begin{array}{l}\text { Fragaria vesca, } \text { Potentilla aurea, } \\
\quad \text { P. crantzii, P. erecta }\end{array}$ & & 0.018 & Broström et al. 2004 \\
\hline Rubiaceae & $\begin{array}{l}\text { Cruciata laevipes, Galium anisophyllum, } \\
\text { G. odoratum }\end{array}$ & & 0.019 & Broström et al. 2004 \\
\hline Trollius europaeus & Trollius europaeus & 21.3 & 0.013 & \\
\hline
\end{tabular}

The fall speed of pollen types used in Prentice's model is extracted from the literature or calculated with Stoke's law (Gregory 1973) (see text for more explanations)

\section{Extended $\mathrm{R}$ value (ERV) models to estimate pollen productivity}

The parameters in Eq. (1), the pollen representation factor $\left(\alpha_{i}\right)$ and the background component (y-intercept), are estimated for individual taxa, using erv_v6.1.exe, an ERVmodel program (Sugita, unpublished; Sugita 1994; Sugita et al. 1999; Nielsen and Sugita 2005). Three ERV submodels are available. Each submodel estimates relative pollen productivity and background pollen by comparing one set of pollen data with multiple vegetation data sets, each collected from different distances around the pollen sampling points. When plant abundance is properly distance-weighted, the pollen representation factor $\left(\alpha_{i}\right)$ can be considered as the pollen productivity estimate of individual taxa (Prentice 1985; Sugita 1994). We used three different methods to calculate distance-weighted plant abundance at given distances (see the next subsection), and then used the plant abundance data as inputs into the ERV-model program.

The meaning and dimension of the intercept (the background component) vary among ERV submodels:

ERV submodel 1-The background component represents the proportion of pollen loading coming from beyond the area of vegetation data compared, relative to the total pollen loading for each taxon (Parsons and Prentice 1981).

ERV submodel 2-The background component represents the ratio of pollen loading, which comes from beyond the area of the vegetation data used for data analysis, to the total sum of plant abundance within the area of the vegetation data (Parsons and Prentice 1981).
ERV submodel 3-The background component represents the amount of pollen loading coming from beyond the area of the vegetation data used for data analysis (Sugita 1994).

The ERV-model program uses a maximum likelihood method to calculate PPEs and background components, assuming that pollen proportions follow a multinomial distribution (Parsons and Prentice 1981; Sugita 1994). The program calculates the "likelihood function scores" (Prentice and Webb III 1986; Sugita 1994), which represent the negative value of the Support function (Sugita 1994). This means that the lower the "likelihood function score", the higher the probability of getting a good fit of the observed data (pollen and vegetation) to the model using the estimated parameters (Bunting et al. 2004; Sugita 1994). The likelihood function scores are plotted as a function of distance from the pollen sampling point, and the distance where the curve reaches an asymptote that represents the "relevant distance", or the radius of the "relevant source area of pollen" (RSAP) (Sugita 1994, 1998, 2007b; Sugita et al. 1999). In other words, it is the distance (or the radius of the vegetation survey) beyond which the fit of the pollen-vegetation data to the model doesn't improve (e.g. Sugita 1994). Therefore, the best PPEs will be obtained using the vegetation data from the area around the sampling site that represents the RSAP.

Although the identification of this distance is usually estimated visually (Broström et al. 2004, 2005; Bunting et al. 2004; Bunting et al. 2005), a more objective approach has been developed to find the appropriate value (Sugita 2007b). It has been used previously by Nielsen and Sugita (2005), Sugita (2007b) and was chosen in this study as well. It uses a moving-window linear regression to identify 
the distance at which the slope of the likelihood function scores becomes not significantly different from zero for consecutive intervals of e.g. $100 \mathrm{~m}$. The RSAP is defined as the mid point of the window.

PPEs for each taxon are obtained by averaging all the PPE values of the taxon and their standard errors between the RSAP and the maximum surveyed distance (Broström et al. 2004); this is done to smooth out variations in the PPE values obtained for distances larger than the RSAP. Poaceae is set as the reference taxon $(\alpha=1.0)$ since it is present in all the sites and has the largest gradient in both pollen and vegetation proportions. The other ten taxa are calculated relative to Poaceae.

\section{Distance-weighting methods}

A series of ERV-model analyses were run using the three ERV submodels and different distance-weighting functions applied to the vegetation data, i.e. 1/d (Prentice and Webb III 1986), $1 / d^{2}$ (Calcote 1995; Webb III et al. 1981), and taxon specific distance-weighting (Prentice 1985; Sugita 1994). In this study, Prentice's model (Prentice 1985) was used for taxon specific distanceweighting. It was developed for the case of pollen deposition at one point in the centre of a circular basin (Prentice 1985, 1988) and is therefore relevant to pollen data from moss polsters (Sugita 1993). The model takes into account the distance between the plant and the pollen sampling point, and the transportability of the pollen grain specific to each taxon. It expresses the movement of small particles from a ground source, using an atmospheric diffusion model (Sutton 1953); the latter integrates a turbulence parameter, a vertical diffusion coefficient, wind speed and fall speed of each pollen taxon. In the models, the two first atmospheric factors are treated as constants, using the prescribed values for neutral atmospheric conditions (Chamberlain 1975; Prentice 1985). Wind speed was set to $3 \mathrm{~m} / \mathrm{s}$, consistent with many other simulation and empirical studies (Broström et al. 2004; Bunting et al. 2004; Sugita 1994; Sugita et al. 1999). Such a value can be considered as an average of wind speed recorded in our study (Bloesch and Calame 1994); however, wind speed can vary greatly in the area (from 2.1 to $7.8 \mathrm{~m} / \mathrm{s}$ ), depending on the exposure and elevation of the sites. Values for the fall speed of pollen (Table 2) are taken from the literature (Broström et al. 2004; Eisenhut 1961; Gregory 1973; Sugita 1993, 1994). When not available in the literature, they were estimated from size measurement (following Beug 2004) and Stoke's law (Gregory 1973). The fall speeds of pollen for individual taxa required for calculations in this paper are listed in Table 2.

\section{Parameter values and data sets used}

Percentage cover of the selected 11 taxa in the vegetation was available for each 1 metre increment between 0 and 1,500 $\mathrm{m}$ around each of the selected pollen sampling points (19). ERV submodel 3 (Sugita 1994) requires absolute plant abundance; in this study, percentage cover for each taxon was transformed into projection area $\left(\mathrm{m}^{2} / \mathrm{m}^{2}\right)$, which was considered a reasonable measure of absolute plant abundance.

In order to calculate distance-weighted plant abundance, it is necessary to set up the size of the "sedimentary basin" (Prentice 1985; Sugita 1994). However the radius of the basin, $R$, is difficult to determine for moss polster sites. Taxon-specific weighting methods, such as Prentice's model, would weight heavily the amount of plant abundance within a few $\mathrm{cm}$ when $R=0 \mathrm{~m}$ (Mazier 2006; Sugita unpublished). Thus, setting $R=0 \mathrm{~m}$ appears inappropriate. Our preliminary analysis shows that, when $R>0 \mathrm{~m}$ and $R<2-5 \mathrm{~m}$, estimates of RSAP and PPEs using pollen data from moss polsters and distance-weighted plant abundance become robust and consistent (Mazier 2006). In this paper, we set $R$ to $0.5 \mathrm{~m}$, as in Broström et al. 2004, 2005. The implications of the size selection of the basin radius for moss polster samples on the PPEs and RSAP estimates will be further discussed and published elsewhere.

\section{Results}

\section{Relevant source area of pollen}

The estimates of RSAP using three ERV submodels and three distance-weighting functions, as well as the corresponding likelihood function scores (i.e. the average of all

Table 3 Estimates of relevant source area of pollen (m) using the moving-window method (Sugita 2007b), and applying various combinations between ERV submodels, and distance-weighting methods

ERV submodel 1 ERV submodel 2 ERV submodel 3

\begin{tabular}{lccc}
\hline \multicolumn{3}{l}{ Relevant source area of pollen $(\mathrm{m})$} \\
$1 / d$ & 244 & 644 & 706 \\
$1 / d^{2}$ & 64 & 261 & 291 \\
$\begin{array}{l}\text { Prentice's } \\
\quad \text { model }\end{array}$ & 284 & 604 & 694 \\
Likelihood function scores & & \\
$1 / d$ & 15,567 & 15,615 & 15,615 \\
$1 / d^{2}$ & 15,812 & 15,906 & 15,906 \\
$\begin{array}{l}\text { Prentice's } \\
\text { model }\end{array}$ & 15,609 & 15,682 & 15,682 \\
\end{tabular}

The likelihood function scores corresponding to the estimated radius of the RSAP are an average of the likelihood function scores of the RSAP distance up to the maximum vegetation distance survey 
scores between the RSAP distance and the maximum distance of the vegetation survey) are presented in Table 3 . Figure 3a shows the likelihood function score plots obtained with the three submodels using one of the distance-weighting functions $(1 / d)$. All plots are approaching an asymptote.

ERV submodels 2 and 3 produced comparable values of RSAP and likelihood function scores, independent of the distance-weighting used (Table 3). Regardless of the ERV submodel, the distance at which the asymptote is reached is shortest when $1 / d^{2}$ is used as distance-weighting (Fig. 3b). ERV submodel 1 produces lower estimate of RSAP and likelihood function scores than the two other submodels. Because the lowest likelihood function scores theoretically correspond to the best goodness-of-fit between data and model (Sugita 1994), the ERV submodel 1 with inverse distance-weighting $(1 / d)$ might be the best method of calculating PPEs in the case of our dataset.

Pollen-vegetation relationship

The ERV submodels try to find the best linear relationship between pollen and vegetation by adjusting the parameters, i.e., PPE and background pollen. Results from ERV submodel 2 and $1 / d^{2}$ are not presented below, since firstly ERV submodels 2 and 3 produce comparable results (not shown), and secondly $1 / d^{2}$ shows higher likelihood function scores independent of the ERV submodel used,
Fig. 3 Likelihood function score plots for (a) three ERV submodels and $1 / d$ as distanceweighting function, (b) ERV submodel 1 and three distanceweighting function (Prentice's model, $1 / d$ and $\left.1 / d^{2}\right)$. The RSAP is identified by the movingwindow linear regression approach (Sugita 2007b)

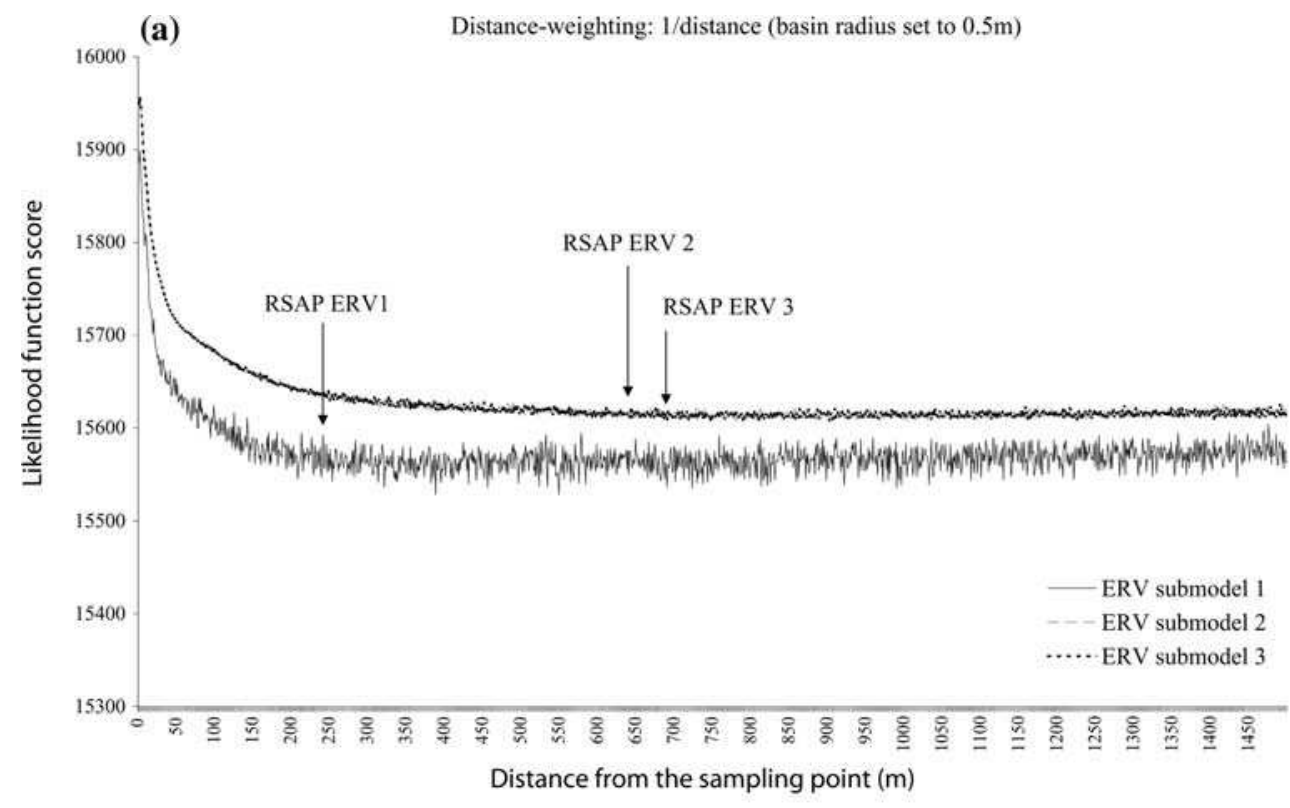

(b)

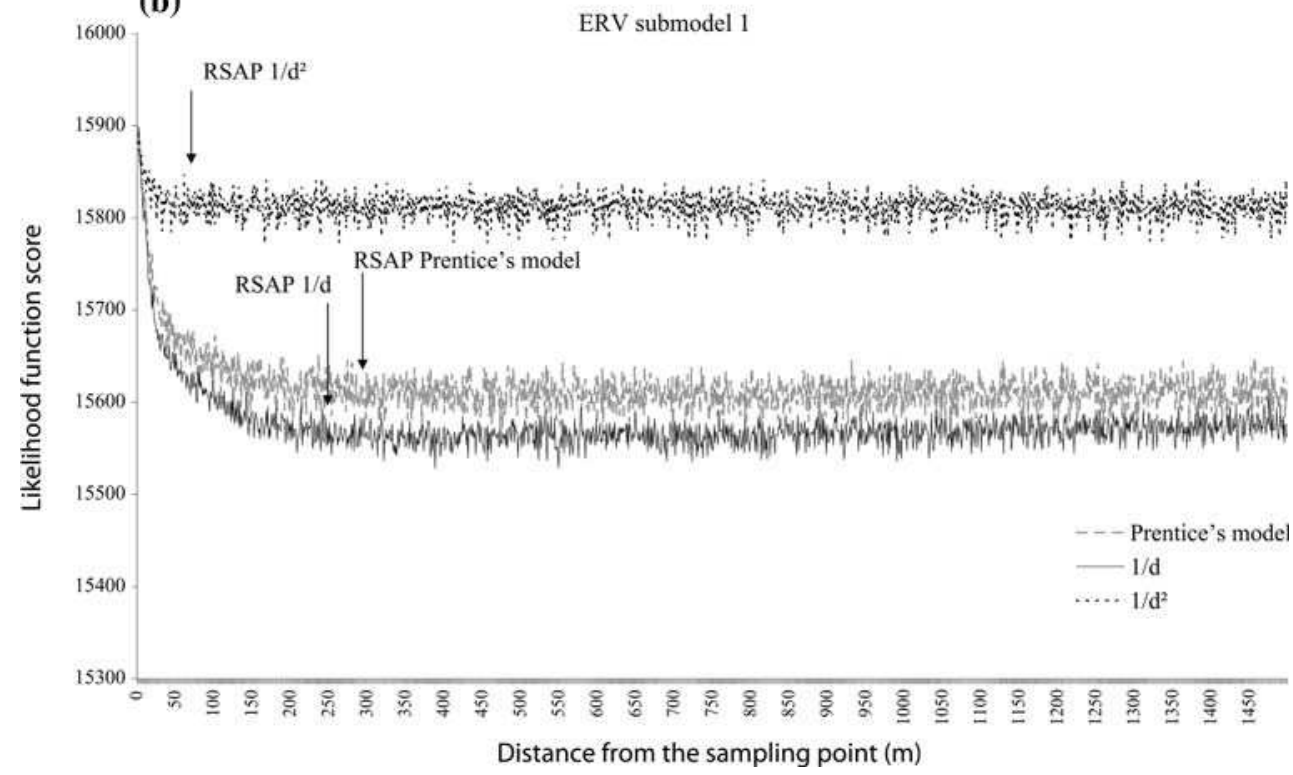


Fig. 4 Scatter plots of pollen and vegetation data for the 11 taxa included in the analysis, within the radius of the relevant source area (see Table 3). The results obtained with Prentice's model and $1 / d$ distance-

weighting are both shown. (a)

Original data of pollen proportion versus vegetation proportion, (b) ERV submodel 3 with relative pollen loading versus absolute vegetation proportion, (c) ERV submodel 1 with pollen proportion versus adjusted vegetation proportion
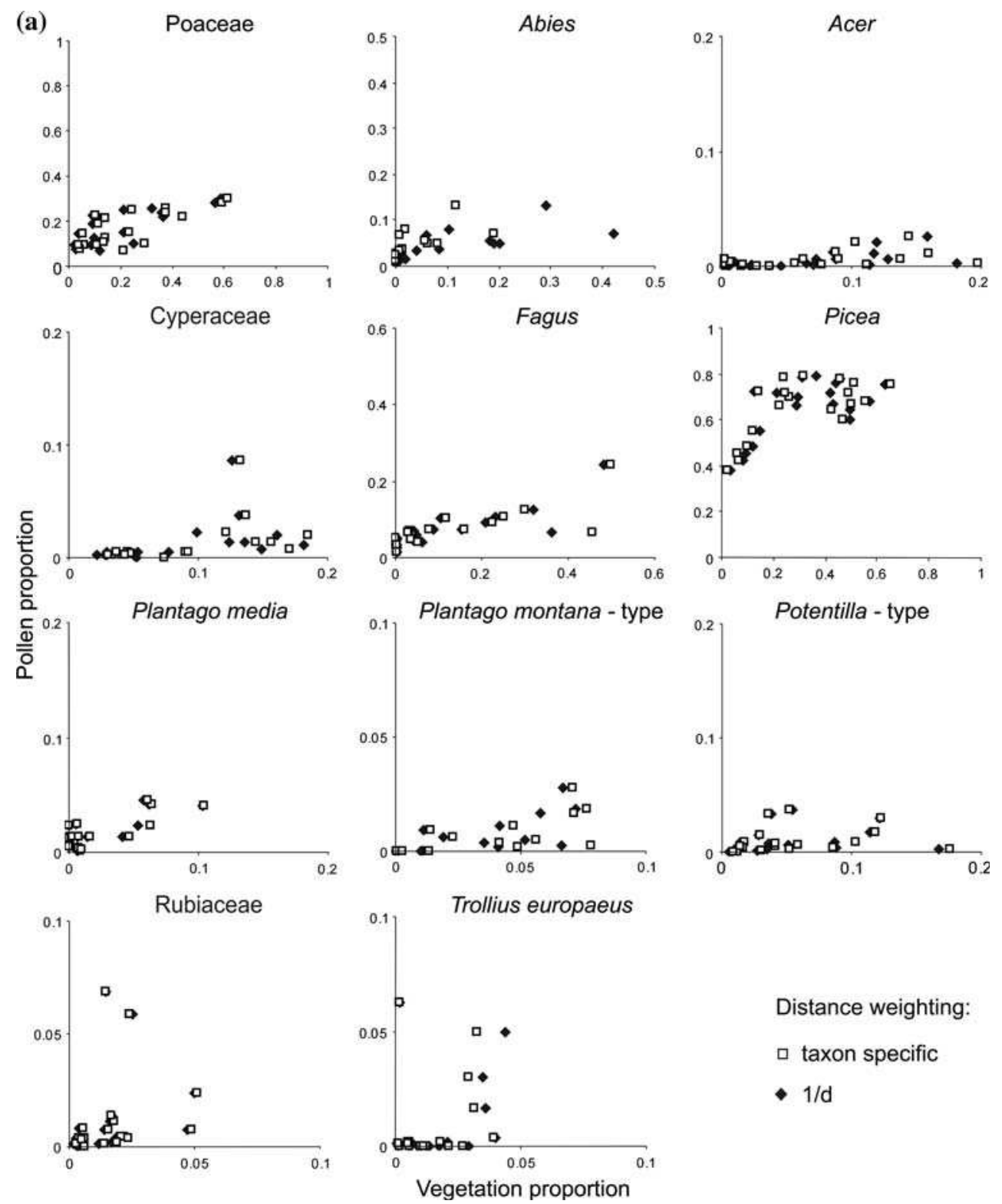

Distance weighting:

ㅁ taxon specific

- $1 / \mathrm{d}$ suggesting that the distance-weighting method is not appropriate for our dataset and analysis.

The goodness-of-fit of the data to the model-estimated relationship can be visualized on scatter diagrams (pollen versus vegetation). The results are plotted on the axes of pollen proportion and adjusted vegetation pollen proportion (ERV submodel 1) and the axes of relative pollen loading and absolute vegetation abundance (ERV submodel 3).

\section{Pollen proportion versus vegetation proportion (Fig. 4a)}

Figure 4a shows the relationship between original (uncorrected data) pollen proportion and distance- weighted plant proportion (Prentice's model and $1 / d$ ) for the 11 selected taxa. Poaceae, Fagus and Picea show a large variation in proportions among the 19 sites in both pollen (0.0-0.4 or 0.8$)$ and plant proportion (0.0-0.4 or 0.7). Poaceae show a comparable variation with both distance-weightings. Cyperaceae is characterised by an intermediate variation in pollen $(0.0-0.1)$ and vegetation (0.0-0.2). Rubiaceae and Trollius are equally represented in both pollen (0.0-0.07) and vegetation (0.0-0.05). Four other taxa (Acer, Plantago media, Plantago montanatype and Potentilla-type) are less frequent in the pollen data $(0.00-0.07)$ than in the vegetation data $(0.0-0.2)$. In general, the two methods of distance-weighting produce similar patterns. 
Fig. 4 continued

(b)
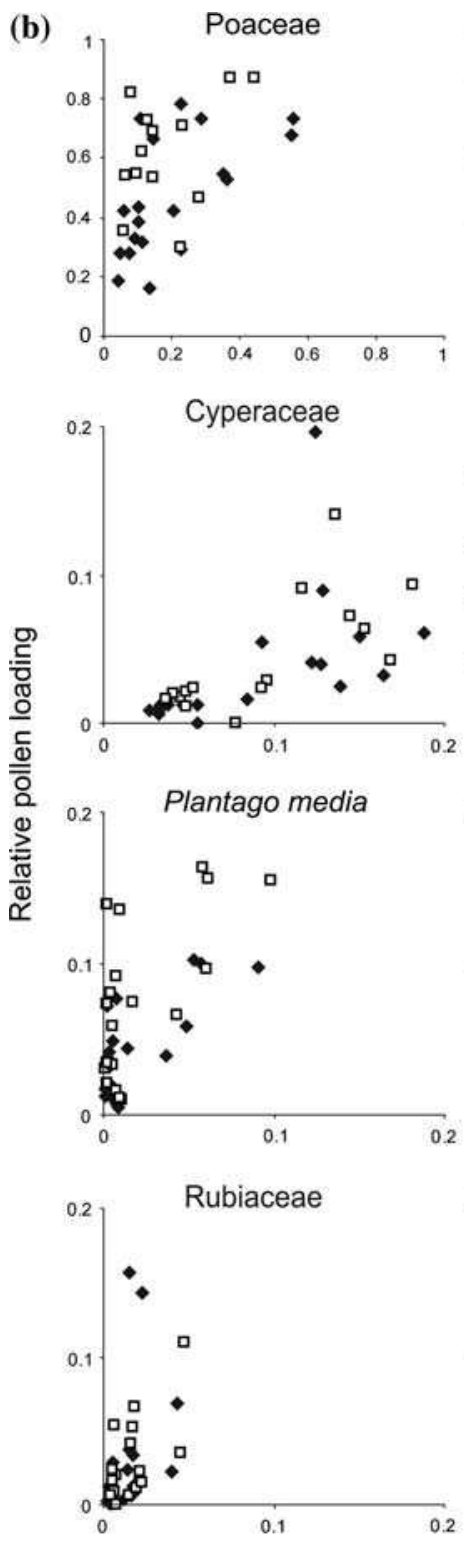
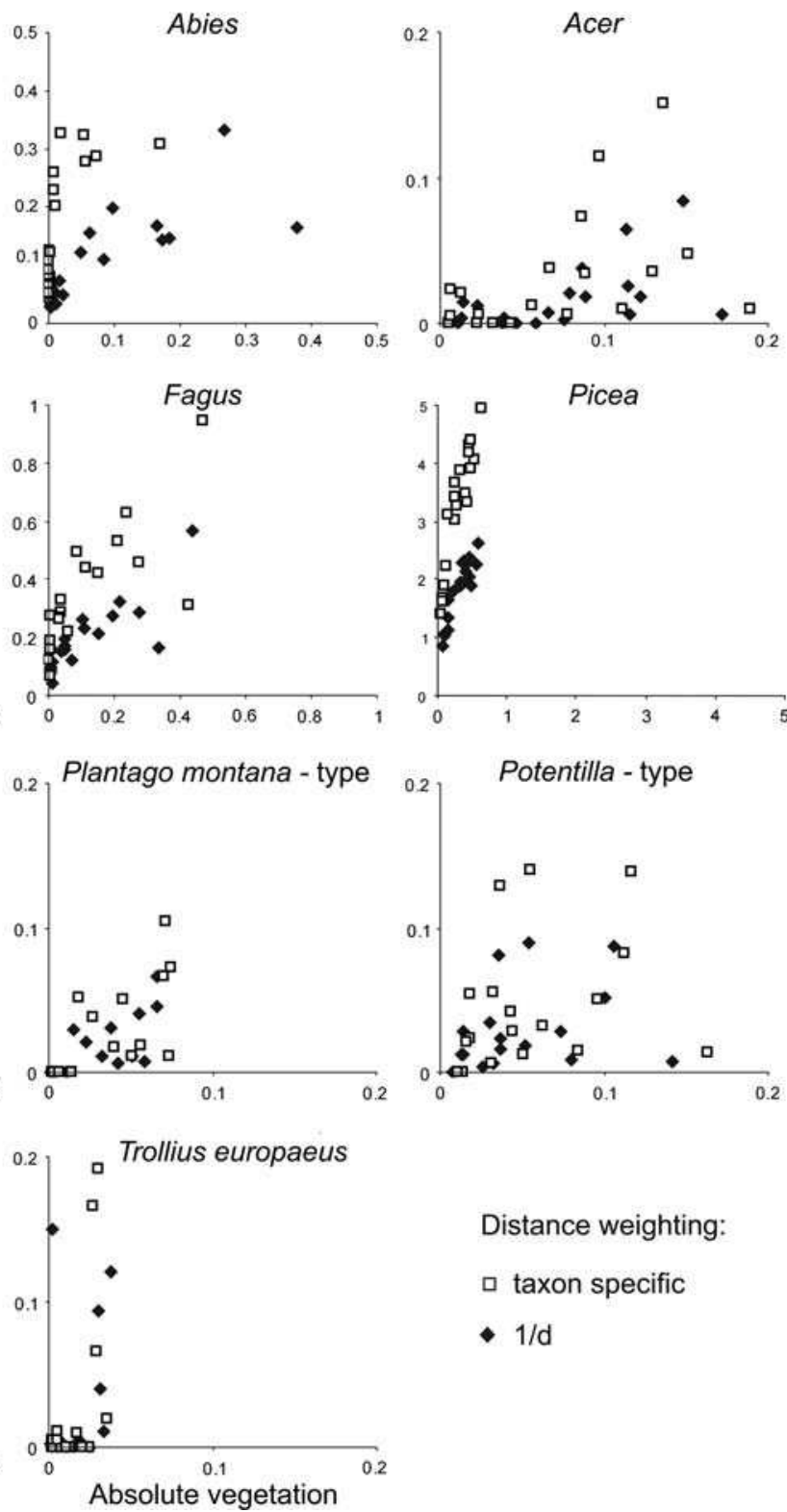

Distance weighting:

口 taxon specific

- $1 / \mathrm{d}$
ERV submodel 3-relative pollen loading versus absolute vegetation abundance (Fig. 4b)

ERV submodel 3 estimates two parameters from the linear pollen-vegetation relationship (relative pollen loading versus absolute plant abundance), i.e. the slope $\left(\alpha_{i}\right)$ and intercept $\left(\omega_{i}\right)$ for each individual taxon (Eq. 1). The linear relationship is established for the RSAP for each distanceweighting method (Fig. 4b); both methods result in a RSAP of ca. $700 \mathrm{~m}$ (Table 3). ERV submodel 3 appears not to improve the pollen-vegetation relationship, except for Picea. For some taxa (such as Abies, Acer, Cyperaceae, Plantago montana-type and Potentilla-type) the submodel does not produce any linear relationship, and the plots look different depending on the distance-weighting used. For example, the pollen-vegetation relationship for Abies shows a higher slope (i.e. a higher PPE) when Prentice's model is used than when $1 / d$ is applied.

ERV submodel 1-pollen proportion versus adjusted vegetation proportion (Fig. 4c)

Using the ERV submodel 1, the relationship between pollen proportion and adjusted vegetation proportion is established for the RSAP obtained when $1 / d$ and Prentice's model are applied, at ca. 250 and $300 \mathrm{~m}$, respectively (Table 3). Figure $4 \mathrm{c}$ shows similar linear relationships, suggesting that good data-model fits are achieved with both distance-weighting methods. However, some discrepancies 
Fig. 4 continued
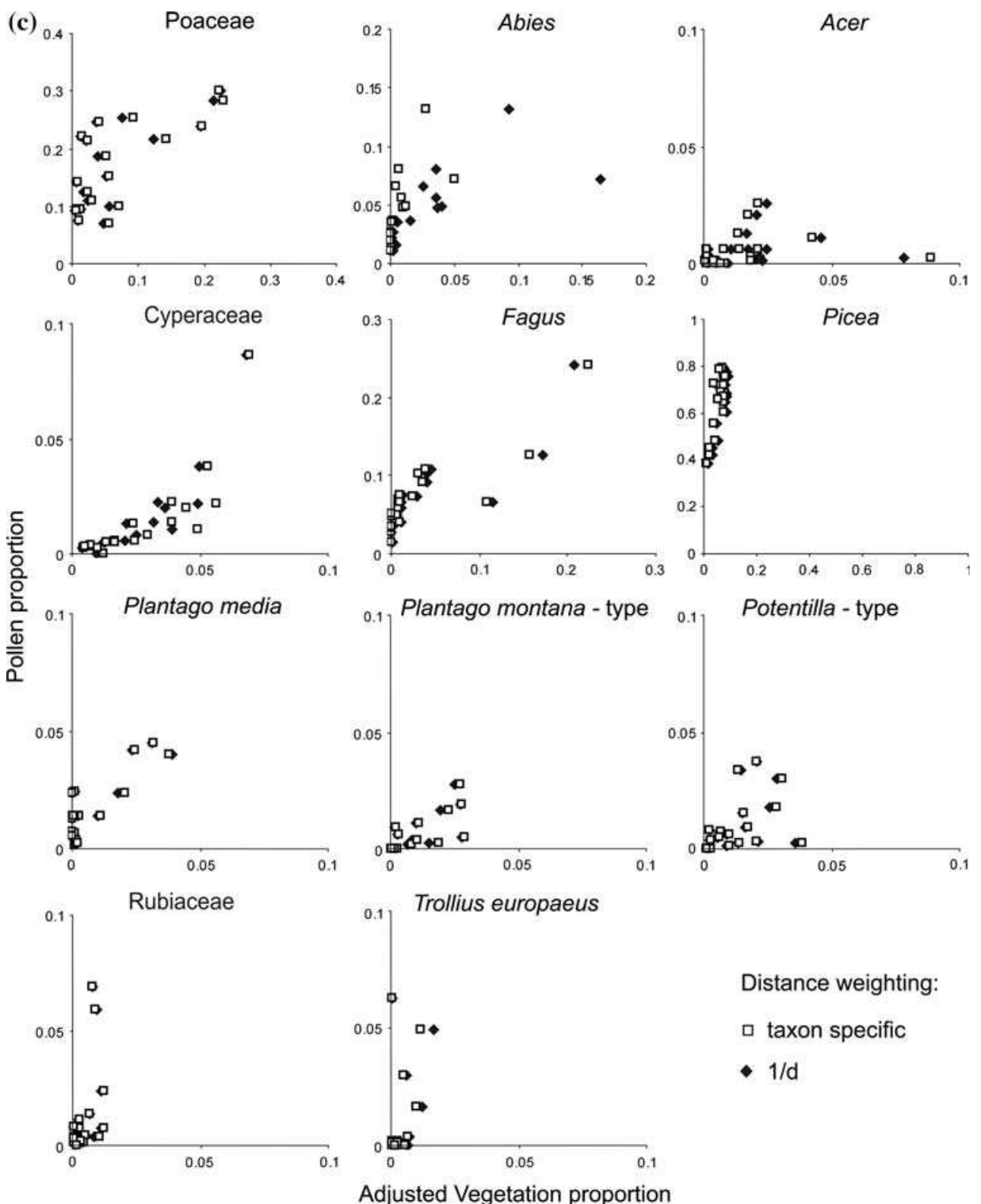

are observed for Abies, Picea and Trollius europaeus. When using $1 / d$, the plots for these taxa indicate lower slopes, especially for Abies, which means that the obtained PPE is lower when $1 / d$ rather than Prentice's model is used (Fig. 5).

Therefore, the ERV submodel 1 produces consistent linear relationships for most taxa, suggesting that this model fits best to our dataset.

Pollen productivity estimates

PPEs were calculated for the 11 selected taxa using different combinations of the submodels and the distance- weighting functions (Table 3). Two different distanceweightings, $1 / d$ and Prentice's model, were compared when ERV submodels 1 and 3 were used (Fig. 5). The two distance-weighting methods, independent of the submodel used, produced similar PPE values when standard errors are taken into account, except for Abies, Picea and Trollius europaeus that have higher PPEs when Prentice's model is applied. In general, ERV submodel 1 produces higher PPEs than ERV submodel 3. However, PPEs overlap when standard errors are considered, except for Picea and Trollius europaeus.

Using ERV submodel 1 with $1 / d$, Acer, Cyperaceae, Plantago montana-type and Potentilla-type have lower PPEs than Poaceae, i.e. below 1. Abies, Fagus, Plantago 
Fig. 5 Pollen productivity estimates (PPEs) with standard deviation for eleven key taxa of the pasture-woodland vegetation. Poaceae is set to unity. PPE values for the other taxa are expressed relative to Poaceae. The PPEs obtained with ERV submodels 1 and 3 and both Prentice's model and $1 / d$ distance-weighting function are shown

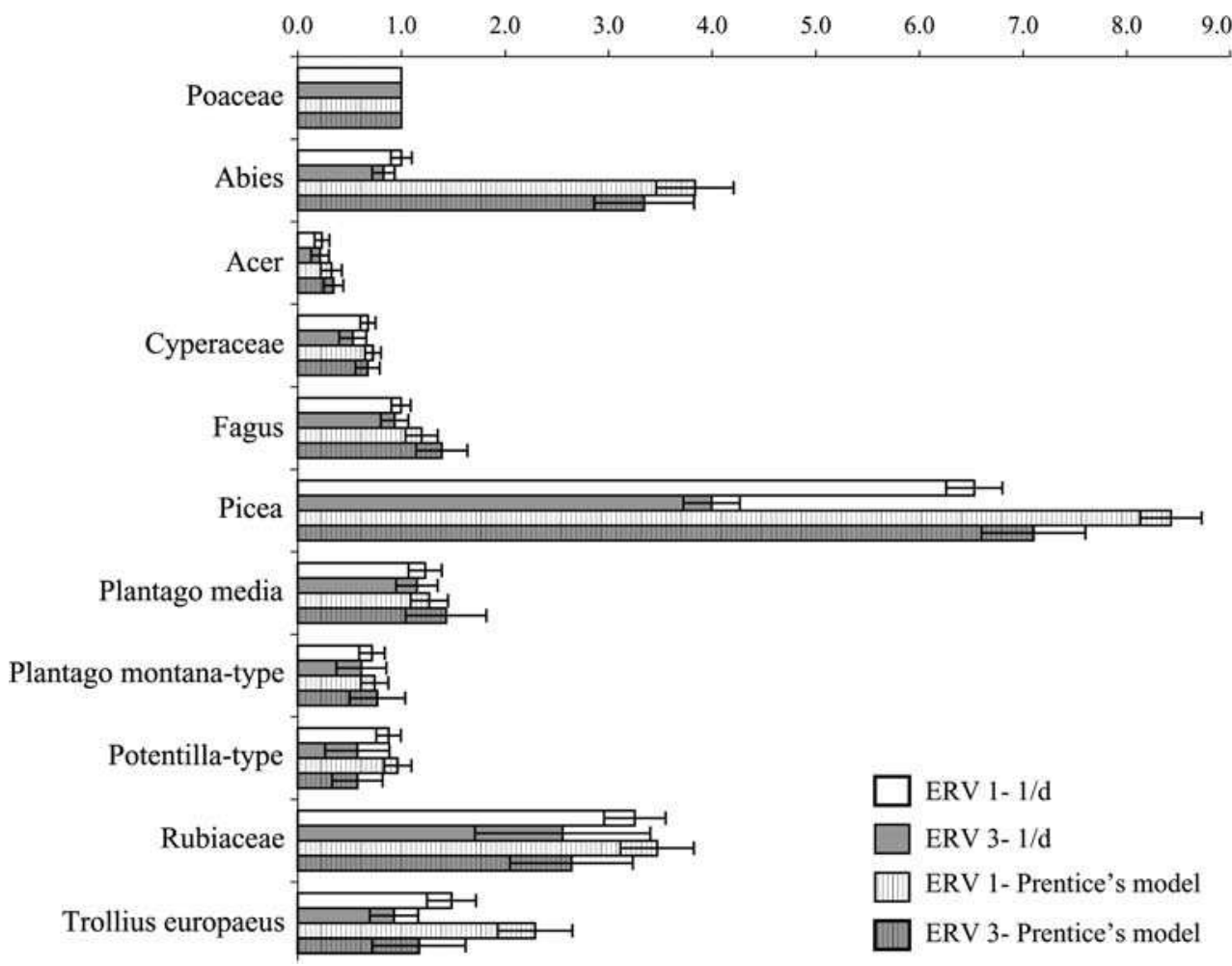

media and Trollius europaeus have relative PPEs between 1.0 and 1.5. Picea and Rubiaceae have significantly higher PPEs, between 3.3 and 6.5. Using ERV submodel 1 and Prentice's model, the results are very similar, expect for Abies, Picea and Trollius europaeus that have higher PPEs.

\section{Discussion}

Distance-weighting method

One of the key challenges in applying ERV submodels is the choice of appropriate ways to measure vegetation composition when developing calibration data sets for parameter estimation, such as PPE and the background pollen component. Widespread aerial dispersal of pollen requires that some form of distance-weighting be applied to the vegetation data in order to approximate a "pollen sample's view" of the landscape (e.g. Prentice and Webb III 1986). Distance-weighting applied in pollen-vegetation calibration and landscape reconstruction has varied widely, ranging from equal weighting to all individual plants at all distances (Calcote 1995; Jackson 1990; Nielsen and Sugita 2005; Prentice et al. 1987), to giving a greater weight to nearby vegetation by inverse distance-weighting (1/d) (Broström et al. 2004; Nielsen and Odgaard 2005; Nielsen and Sugita 2005; Prentice and Webb III 1986) or inversesquared distance $\left(1 / d^{2}\right)$ (Broström et al. 2004; Bunting et al. 2005; Calcote 1995; Jackson and Kearsey 1998; Nielsen and Sugita 2005; Webb III et al. 1981), and application of pollen dispersal models such as in Prentice's model (Prentice 1985) and Sugita's model (Sugita 1994; Broström et al. 2004, 2005; Bunting and Middleton 2005; Calcote 1995; Nielsen 2004; Nielsen and Odgaard 2005; Nielsen and Sugita 2005).

Comparing the obtained estimates of RSAP using these different distance-weighting methods and the three ERV submodels indicates that these methods produce significantly different results (Table 3 ). When $1 / d^{2}$ is applied, the likelihood function scores decrease rapidly and reach an asymptote at a shorter distance than the two other methods (Fig. 3b). This was also shown by Bunting et al. (2005) and Jackson and Kearsey (1998). Although Calcote (1995) concluded that $1 / d^{2}$ produced robust results, this distanceweighting method produces the highest likelihood function scores in our case, suggesting that the goodness of fit of our pollen-vegetation data to the model is not as good with this method as with the other two (1/d and Prentice's model). When 1/d and Prentice's model are applied, the curves of likelihood function scores are very similar, and an asymptote is reached at around the same distance (RSAP). However $1 / d$ results in the lowest likelihood function scores independent of the ERV submodel used and produces the best goodness of fit between the pollenvegetation data and the ERV model, which was also the case in the study by Nielsen (2004) in Denmark. Therefore, 
$1 / d$ is more appropriate to calculate PPEs, and is theoretically sound (Sugita 1994).

When 1/d and Prentice's model are applied, PPEs are similar for most pollen taxa when standard errors are taken into account, except for Abies, Picea and Trollius europaeus (Fig. 5). PPEs are influenced by the distance-weighting used in the case of very heavy (Abies, Picea) and very light (Trollius europaeus) pollen types. Abies produces 3.8 times more pollen with Prentice's model than with $1 / d(\alpha \approx 1.0)$. Prentice's model integrates the aerodynamic properties of Abies, with a high fall speed of $0.12 \mathrm{~m} \mathrm{~s}^{-1}$, which implies that distance-weighted vegetation proportions become lower than when $1 / d$ is used, therefore the PPEs get higher. Moreover, the differences observed in the likelihood function scores are not large, so the PPE values obtained with Prentice's model might be preferred and considered as more robust (Broström et al. 2004; Bunting and Middleton 2005; Soepboer et al. 2007a). Soepboer et al. (2007a) observed the same trend for Abies in their dataset when applying the Sugita model (Sugita 1994) and 1/d as distance-weighting to calculate PPEs using surface pollen assemblages from small lakes of the Swiss Plateau.

It should be stressed here that both the distanceweighting method and the size of increments for the vegetation input (width of the circles) could affect PPEs (Jackson and Kearsey 1998). Vegetation weighting obviously depends on the size of the increments, as it is a function of the distance from the pollen sampling point; the finer the vegetation data increment, the greater the proportional weight on the vegetation near the site of pollen deposition. In this study, very detailed vegetation data are available for each 1 metre increment between 0 and $1,500 \mathrm{~m}$ around each of the selected sampling points. This fact has to be taken into account when PPEs obtained in different studies are compared.

\section{ERV models}

ERV submodels 2 and 3 give very similar results for PPEs and pollen-vegetation relationships (not shown in this paper). In ERV submodel 3, the input vegetation data are expressed as mean plant abundance per unit area, whereas in ERV submodels 1 and 2, the vegetation data are expressed as proportions of total area (percentages). When non pollen producing areas (rocks, roads, water, etc.) are not included in the analysis, which is the case here, the two ways of expressing the vegetation (projection area per unit area and percentages) are the same values (not the same dimension), i.e. the input vegetation data is the same in both cases. This could explain the similar results as ERV submodels 2 and 3 include similar equations to linearize the pollen-vegetation relationship.
ERV submodels 1 and 3 produce quite similar PPEs, except for Picea and Trollius europaeus. ERV submodel 1 seems to be the most reliable model in our semi-open landscape. In theory, ERV submodel 3 is considered to be especially appropriate for the analysis of pollen-vegetation data in small scale studies (i.e. moss polsters and forest hollows), when accurate measurements of plant abundance are available (Sugita 1994). Therefore, it was used to calculate PPEs in other regions (Broström et al. 2004; Bunting et al. 2005; Soepboer et al. 2007a). In our case, ERV submodel 1 is more appropriate because the dataset does not include well-dispersed pollen types such as Pinus and Betula involving high background pollen for these species. Moreover, submodel 1 is strengthened when the dataset includes vegetation data from a sampling area that is large enough to minimize the effect of background pollen. In other words, submodel 1 is robust as long as the background pollen deposition for each taxon is a small proportion of the total pollen deposition at each site $\left(\omega_{i}<<p_{i k}\right.$ in equation 1$)$ (Prentice and Parsons 1983; Sugita 1994). In theory, as the vegetation sampling radius increases to incorporate more distant pollen sources, the background pollen component decreases and the PPEs become more stable and consistent. In our case, the RSAP was estimated to ca. $300 \mathrm{~m}$, and the vegetation data was surveyed up to $1,500 \mathrm{~m}$. Using ERV submodel 3, the maximum likelihood estimates of background pollen loading can be directly converted, for each taxon, into pollen proportion coming from beyond the RSAP (Sugita 1994). Estimates of the background pollen percentage were calculated for the 11 selected taxa using Prentice's model. The sum of average background pollen percentages of all taxa represents only $20.7 \%$ of the total pollen loading. Two main taxa (Picea and Poaceae) represent $17 \%$ (12.5 and $4.5 \%$ respectively) of the pollen coming from beyond the RSAP. Therefore, the PPEs obtained using submodel 1 can be considered as the most appropriate in the case of our semi-open landscape. One should not forget that the ERV submodels do not incorporate the effects of topography on pollen dispersal, which could be a serious problem in mountainous regions, such as our investigation area. The relief of the area is composed of a succession of tree-covered crests and elongated valleys with poor tree cover. Wind speed might be significantly influenced by this geomorphology, and the valleys can be compared to wind corridors where wind speed might be higher than on the wooded slopes. Bloesch and Calame (1994) showed that wind speed varies greatly according to the exposure and elevation of the sites (from 2.1 to $7.8 \mathrm{~m} / \mathrm{s}$ ). Nielsen (2004) demonstrated that wind speed influences the pollen dispersal function, especially for pollen types with high fall speeds. However, Nielsen and Sugita (2005) argue that increasing the wind speed will mainly increase the part of the pollen assemblages that makes up the regional 
background, which in theory should be the same among moss polsters in our region (Parsons and Prentice 1981; Prentice and Parsons 1983; Sugita 1994). Another question that should be kept in mind is the possible influence of vegetation pattern and height on wind speed. As the models treat herb and tree pollen as if they originated from the same level, the vegetation height is not taken into account in the calculation so far, but it will be integrated in future models (Bunting and Middleton 2005).

Pollen assemblages from moss polsters

Pollen assemblages from moss polsters may be sensitive to annual variations in pollen production, as the exact number of years represented is generally not known, and assumptions on that differ significantly between authors (Boyd 1986; Bradshaw 1981; Caseldine 1981; Crowder and Cuddy 1973; Cundill 1991; Heim 1970; Mulder and Janssen 1998, 1999; Räsänen et al. 2004). If pollen assemblages from moss polsters do not represent an average of several years of pollen deposition, annual variations in pollen productivity (Hicks et al. 2001; Van der Knaap et al. 2000; Van der Knaap et al. 2001; Van der Knaap and van Leeuwen 2003) could be critical for calculation of PPEs. Significant interannual variation can be either climate- or land use-induced. In the same study area as ours, Sjögren et al. (2006) used pollen accumulation rates from a Sphagnum peat hummock to assess the variation in pollen productivity related to climatic parameters over a period of 25 years (A.D. 1975-2000). This study reveals that pollen productivity of many trees appears to be affected by climatic conditions, however not during the main growing season (summer). The pollen production of Abies is positively related to both winter and spring temperature, Acer and Fagus are respectively positively and negatively correlated to winter temperature. The authors argue that frost damage, failed hibernation and premature flowering are more critical than summer warmth. They also emphasize that the explanatory climatic variables affecting pollen productivity could be different according to the location and altitude of the site, i.e. the altitudinal limit could be specific for each plant taxon involved. The question of the possible role of interannual variation in pollen productivity for the calculation of PPEs and their use in vegetation reconstruction needs further research.

\section{Conclusion}

Pollen productivity estimates have been produced for 11 plant taxa characteristic of pasture woodland landscapes in the Jura Mountains. In this semi-open vegetation, most of the taxa have PPEs equal to (Fagus, Plantago media and Potentilla-type), or higher (Abies, Picea, Rubiaceae and Trollius europaeus) than Poaceae (PPE = 1).

The obtained PPEs and RSAP values show some discrepancies depending on the ERV submodels and distanceweighting function used. ERV submodel 1 with $1 / d$ as weighting function produces lower likelihood function scores and would be, in theory, the most accurate model to estimate PPEs and RSAP. However, PPEs also depend on the distance-weighting used for heavy pollen taxa (e.g. Abies). In this case, Prentice's dispersal model is more appropriate. Surprisingly, the best fit to our data was obtained with ERV submodel 1 . This is probably due to the fact that well-dispersed pollen types are not included in the selected dataset. The RSAP for moss polsters in our case is ca. $300 \mathrm{~m}$. This value is very close to that obtained in the open and semi-open cultural landscapes $(R=400 \mathrm{~m})$ of southern Sweden (Broström et al. 2005). Because one of the most influential factors on RSAP is vegetation structure (or the grain of the vegetation mosaic) (e.g. Bunting et al. 2004, Broström et al. 2005), and given the vegetation data was collected at very similar spatial scales, the similar results in the Jura Mountains and southern Sweden would imply that these two landscape types have comparable vegetation structures/mosaics.

Our PPEs have been compared to other PPEs from various regions and countries of Europe in the synthesis by Broström et al. (2008, this volume). These regions differ in terms of climate, geomorphology, plant species composition, and land-use characteristics at both local and regional spatial scales, which might result in different background pollen components. To fully understand pollen representation of different taxa and investigate the variation in pollen productivity within and between species, both RSAP for the basin studied (i.e. moss polsters, hollows, small lakes) and the background pollen need to be considered. These questions will be discussed elsewhere in more depth (Broström et al. 2008, this volume).

The results presented in this paper are an essential contribution to the development of robust tools for the quantitative reconstruction of mountainous landscapes consisting of a mosaic of trees, shrubs, and open grassland in central Europe. Using the novel Landscape Reconstruction Algorithm (Sugita 2007a, b), our PPEs will be used to infer historical landscape patterns in the Jura mountains from fossil pollen assemblages from several peat bogs recently analysed (Sjögren 2005, 2006; Sjögren and Lamentowicz 2007). This approach will help firstly in assessing the processes (in terms of vegetation patterns, composition, cover and openness) controlling the maintainance of pasture woodlands and their biodiversity, and secondly in suggesting management strategies for future management of this type of landscape. 
Acknowledgments The study has been made possible with the help of a number of people to whom we are profoundly grateful: Zuzu Gadallah for supervision in the interpretation of vegetation from CIR aerial photos and for organizing the agreement between WSL and Swisstopo for the use of aerial photographs; Jesse Kalwij for sending CIR aerial photos; Sylvain Meier and Patrick Fouvy (Service des Forêts, de la Faune et de la Nature, canton de Vaud) for providing forest inventories; François Gillet for his continuous advice and help in the use of Phytobase software; Anne Vignot for her guidance in the use of GIS software; Florencia Oberli for preparing the pollen samples; Jacqueline van Leuwen for pollen analysis; Thomas Hickler and Jean-Daniel Tissot for spending long hours on computer programming. Thanks to François and his students team, Sylvie, Mireille, Olivier and Cécile for their precious and encouraging assistance during the fieldwork. The manuscript was improved thanks to the helpful comments and suggestions from the two referees, Sheila Hicks and André F. Lotter. This paper is a contribution to the POLLANDCAL (POLlen-LANDscape CALibration) network (http://www.geog.ucl.ac.uk/ecrc/pollandcal/) sponsored by Nordforsk and co-ordinated by M.-J. Gaillard (University of Kalmar, Sweden). We are very thankful to all POLLANDCAL members for useful and inspiring discussions during the numerous network workshops (20012005). Specific thanks are addressed to Anne-Brigitte Nielsen and Per Sjögren for all the discussions we had on the subject of PPEs. This research was funded by the National Centre of Competence in Research (NCCR) Plant survival of the Swiss National Science Foundation.

\section{References}

Andersen ST (1970) The relative pollen productivity and pollen representation of north European trees, and correction factors for tree pollen spectra. Determined by surface pollen analyses from forests. C. A. Reitzels, Kovenhavn

Anderson J, Bugmann H, Dearing JA, Gaillard M-J (2006) Linking palaeoenvironmental data and models to understand the past and to predict the future. Trends Ecol Evol 21:696-704

Beug H-J (2004). Leitfaden der Pollenbestimmung für Mitteleuropa und angrenzende Gebiet. Pfeil, München

Bloesch B, Calame F (1994) L'air du temps. In: Capt G, Jean-PetitMatile O, Reymond J (eds) Le Parc jurassien vaudois. 24 heures, Lausanne, pp 35-45

Boyd WE (1986) The role of mosses in modern pollen analysis: the influence of moss morphology on pollen entrapment. Pollen et spores 28:243-256

Bradshaw RHW (1981) Modern pollen representation factors for woods in South-West England. J Ecol 69:45-70

Broström A, Gaillard M-J, Ihse M, Odgaard B (1998) Pollenlandscape relationships in modern analogues of ancient cultural landscapes in southern Sweden - a first step towards quantification of vegetation openess in the past. Veget Hist Archaeobot 7:189-201

Broström A, Sugita S, Gaillard M-J (2004) Pollen productivity estimates for the reconstruction of past vegetation cover in the cultural landscape of southern Sweden. Holocene 14:368-381

Broström A, Sugita S, Gaillard M-J, Pilesjo P (2005) Estimating the spatial scale of pollen dispersal in the cultural landscape of southern Sweden. Holocene 15:252-262

Broström A, Binney H, Bunting MJ, Duffin K, Fyfe R, Gaillard M-J, Hicks S, Hjelle KL, Mazier F, Meltsov V, Nielsen AB, Poska A, Räsänen S, Soepboer W, von Stedingk H, Sugita S, Suutari H (2008) Pollen productivity estimates of key European plant taxa for quantitative reconstruction of past vegetation-a review. Veget Hist Archaeobot (in press)
Bunting MJ, Middleton D (2005) Modelling pollen dispersal and deposition using HUMPOL software, including simulating windroses and irregular lakes. Rev Palaeobot Palynol 134:185

Bunting MJ, Gaillard M-J, Sugita S, Middleton R, Broström A (2004) Vegetation structure and pollen source area. Holocene 14:651-660

Bunting MJ, Armitage R, Binney HA, Waller M (2005) Estimates of 'relative pollen productivity' and 'relevant source area of pollen' for major tree taxa in two Norfolk (UK) woodlands. Holocene 15:459-465

Calcote R (1995) Pollen source area and pollen productivity: evidence from forest hollows. J Ecol 83:591-602

Caseldine C (1981) Surface pollen studies accross Bankhead Moss, Fife, Scotland. J Biogeogr 8:7-25

Chamberlain AC (1975) The movement of particules in plant communities. In: Monteith JL (ed) Vegetation and atmosphere, vol 1. Principles. Academic Press, London, pp 155-203

Crowder AA, Cuddy DG (1973) Pollen in a small river basin: wilton Creek, Ontario. In: Birks HJ, West RG (eds) Quaternary Plant Ecology. Blackwell, Oxford, pp 61-77

Cundill PR (1991) Comparisons of moss polster and pollen trap data: a pilot study. Grana 30:301-308

Eisenhut G (1961) Untersuchungen über die Morphologie und Ökologie der Pollenkörner heimischer und fremdländischer Waldbäume (translated into English by Jackson ST, Jaumann P, 1989). Paul Parey, Hamburg

Faegri K, Iversen J (1989) Textbook of pollen analysis. Wiley, Chichester

Fagerlind F (1952) The real significance of pollen diagrams. Botaniska notiser 105:185-224

Gaillard M-J (2007) Detecting Human impact in the pollen record. In: Elias SA (ed) Encyclopedia of Quaternary Science. Elsevier, Amsterdam, pp 2570-2595

Gallandat J-D, Gillet F, Havlicek E, Perrenoud A (1995) Typologie et systématique phyto-écologique des pâturages boisés du Jura suisse. Institut de botanique, Université de Neuchâtel

Gillet F, Gallandat J-D (1996) Integrated synusial phytosociology: some notes on a new, multiscalar approach to vegetation analysis. J Veget Sci 7:13-18

Gobat J-M, Duckert O, Gallandat J-D (1989) Quelques relations "microtopographie-sols-végétation" dans les pelouses pseudoalpines du Jura suisse: expemples d'un système naturel et d'un système anthropisé. Bulletin de la société Neuchâteloise des Sciences naturelles 112:5-17

Gregory PH (1973) The microbiology of the atmosphere. Leornard Hill, London, S. 1

Heim J (1970) Les relations entre les spectres polliniques récents et la végétation actuelle en europe occidentale. Dissertation, Université de Louvain, Louvain

Hicks S (2001) The use of annual arboreal pollen deposition values for delimiting tree-lines in the landscape and exploring models of pollen dispersal. Rev Palaeobot Palynol 117:1-29

Hicks S, Tinsley H, Huusko A, Jensen C, Hattestrand M, Gerasimides A, Kvavadze E (2001) Some comments on spatial variation in arboreal pollen deposition: first records from the Pollen Monitoring Programme (PMP). Rev Palaeobot Palynol 117:183-194

Jackson ST (1990) Pollen source area and representation in small lakes of Northeastern United States. Rev Palaeobot Palynol 63:53-76

Jackson ST, Kearsey JB (1998) Quantitative representation of local forest composition in forest-floor pollen assemblages. J Ecol $86: 474-490$

Mazier F (2006) Modélisation de la relation entre pluie pollinique actuelle, végétation et pratiques pastorales en moyenne montagne (Pyrenees et Jura). Application pour l'interprétation des données polliniques fossiles, Thesis Université de FrancheComté/Université de Neuchâtel, Besançon 
Moore PD, Webb JA, Collinson ME (1991) Pollen analysis. Blackwell, Oxford

Mulder C, Janssen CR (1998) Application of Chernobyl Caesium-137 fallout and naturally occurring lead-210 for standardization of time in moss samples: recent pollen-flora relationships in the Allgäuer Alpen, Germany. Rev Palaeobot Palynol 103:23-40

Mulder C, Janssen CR (1999) Occurence of pollen and spore in relation to present-day vegetation in a Dutch heathland area. $\mathrm{J}$ Veget Sci 10:87-100

Nielsen AB (2004) Modelling pollen sedimentation in Danish lakes at c. AD 1800: an attempt to validate the POLLSCAPE model. J Biogeogr 31:1693-1709

Nielsen AB, Odgaard BV (2005) Reconstructing land cover from pollen assemblages from small lakes in Denmark. Rev Palaeobot Palynol 133:1-21

Nielsen AB, Sugita S (2005) Estimating relevant source area of pollen for small Danish lakes around AD 1800. Holocene 15:1006-1020

Parsons RW, Prentice CI (1981) Statistical approaches to R-values and the pollen-vegetation relationship. Rev Palaeobot Palynol 32:127-152

Prentice IC (1985) Pollen representation, source area, and basin size: toward a unified theory of pollen analysis. Quat Res 23:76-86

Prentice IC (1988) Records of vegetation in time and space: the principles of pollen analysis. In: Huntley B, Webb T III (eds) Vegetation history. Kluwer, Dordrecht, pp 17-42

Prentice CI, Parsons RW (1983) Maximum likelihood linear calibration of pollen spectra in terms of forest composition. Biometrics 39:1051-1057

Prentice CI, Webb T III (1986) Pollen percentages, tree abundances and the Fagerlind effect. J Quat Sci 1:35-43

Prentice CI, Berglund BE, Olsson T (1987) Quantitative forestcomposition sensing characteristics of pollen samples from Swedish lakes. Boreas 16:43-54

Punt W, Blackmoire S, Clarke GSC, Hoen PP (1976-1995) The northwest European pollen flora. Elsevier, Amsterdam

Räsänen S, Hicks S, Odgaard BV (2004) Pollen deposition in mosses and in a modified 'Tauber trap' from Hailuoto, Finland: what exactly do the mosses record? Rev Palaeobot Palynol 129:103116

Reille M (1992-1998) Pollen et spores d'Europe et d'Afrique du Nord. Laboratoire de Botanique Historique et Palynologie, Marseille

Sjögren P (2005) Palaeoecological investigatons of pasture woodland in Combe des Amburnex, Swiss Jura Mountains. Thesis, Institut für Planzenwissenschaften, Bern, p 85

Sjögren P (2006) The development of pasture woodland in the southwest Swiss Jura Mountains over 2000 years, based on three adjacent peat profiles. Holocene 16:210-223

Sjögren P, Lamentowicz M (2007) Human and climatic impact on mires-a case study of Les Amburnex mire, Swiss Jura
Mountains. Veget Hist Archaeobot doi: 10.1007/s00334-007-0095-9

Sjögren P, van Leeuwen JFN, van der Knaap WO, van der Borg K (2006) The effect of climate variability on pollen productivity, AD 1975-2000, recorded in a Sphagnum peat hummock. Holocene 16:277-286

Soepboer W, Sugita S, Lotter AF, van Leeuwen JFN, van der Knaap WO (2007a) Pollen productivity estimates for quantitative reconstruction of vegetation cover on the Swiss Plateau. Holocene 1:65-77

Soepboer W, Vervoort JM, Sugita S, LotterAF (2007b) Evaluating Swiss pollen productivity estimates using a simulation approach. Veget Hist Archaeobot doi:10.1007/s00334-007-0128-4

Sugita S (1993) A model of pollen source area for an entire lake surface. Quat Res 39:239-244

Sugita S (1994) Pollen representation of vegetation in Quaternary sediments: theory and method in patchy vegetation. J Ecol 82:881-897

Sugita S (1998) Modelling pollen representation of vegetation. In: Gaillard M-J, Berglund BE (eds) Quantification of land surfaces cleared of forest during the Holocene-modern pollen/vegetation/landscape relationship as an aid to the interpretation of fossil pollen data. Fischer, Stuttgart, pp 1-16

Sugita S (2007a) Theory of quantitative reconstruction of vegetation. I: pollen from large lakes REVEALS regional vegetation composition. Holocene 17:229-241

Sugita S (2007b) Theory of quantitative reconstruction of vegetation II: all you need is LOVE. Holocene 17:243-257

Sugita S, Gaillard M-J, Broström A (1999) Landscape openness and pollen records: a simulation approach. Holocene 9:409-421

Sutton OG (1953) Micrometeorology. McGraw-Hill, New York

Van der Knaap WO, van Leeuwen JFN, Fankhauser A, Ammann B (2000) Palynostratigraphy of the last centuries in Switzerland based on 23 lake and mire deposits: chronostratigraphic pollen markers, regional patterns, and local histories. Rev Palaeobot Palynol 108:85-142

Van der Knaap WO, van Leeuwen JFN, Ammann B (2001) Seven years of annual pollen influx at the forest limit in the Swiss Alps studied by pollen traps: relations to vegetation and climate. Rev Palaeobot Palynol 117:31-52

Van der Knaap WO, van Leeuwen JFN (2003) Climate-pollen relationships AD 1901-1996 in two small mires near the forest limit in the northern and central Swiss Alps. Holocene 13:809828

Vittoz P (1998) Flore et végétation du Parc jurassien vaudois: Typologie, écologie et dynamique des milieux, Université de Lausanne, Lausanne

Webb T III, Howe SE, Bradshaw R, Heide KM (1981) Estimating plant abundances from pollen percentages: the use of regression analysis. Rev Palaeobot Palynol 34:269-300 